TiBuana

Journal of applied Industrial Engineering-University of PGRI AdiBuana

DOI : https://doi.org/10.36456/tibuana.4.01.3172.16-22

\title{
Manufacturing Process Application for Lecture Chair
}

\author{
Achmad Nidhomuz Zaman ${ }^{1}$, Santika Sari ${ }^{2}$ \\ ${ }^{12}$ Industrial Engineering Department, Engineering Faculty, UPN Veteran Jakarta \\ Email:akhmadnidhomuzzaman@upnvj.ac.id
}

\begin{abstract}
A Learning environment is a place where the learning process takes place. In the implementation of the learning process, most student activities are carried out in a sitting position. Therefore the conditions and seating arrangements, the shape of the chairs, the various equipment and facilities that support the teaching and learning process must be a concern. An uncomfortable sitting position can affect the quality of learning. Also, uncomfortable lecture chairs will affect the user's concentration in learning so that this condition will accelerate the onset of fatigue. The application of the production process that we carried out for the manufacture of our redesigned lecture chairs (flexible chair) has been produced with a total time of 370 minutes with parts, namely, the mainframe, headrests, leg rests, back frame, and supporting materials with a total of 5 operators. We hope that this article can help other fellow students to produce an item and make an analysis of the production process.
\end{abstract}

Keywords:learning environment, lecture chairs, production process.

\section{INTRODUCTION}

A learning environment is a place where the learning process takes place. In the implementation of the learning process, most student activities are carried out in a sitting position. Therefore the conditions and seating arrangements, the shape of the chairs, and the various equipment and facilities that support the teaching and learning process must be a concern. An uncomfortable sitting position can affect the quality of learning. Besides, the uncomfortable lecture chairs will also affect the user's concentration in learning so that this condition can accelerate the onset of fatigue.

According to Budiarto (2017), the manufacturing process itself is a process of making workpieces from raw materials to finished or semi-finished goods with or without additional processes. A product can be made in various ways, where the choice of manufacturing method depends on the number of products made, product quality, production facilities owned, and standardization.

According to Alfatiyah, et al (2017) In the teaching and learning process, most student learning activities are carried out sitting down. In the sense of sitting, listening, and writing. So that the comfort and effectiveness of student movements cannot be ignored, because the chair design is good and supports the comfort and effectiveness of student movements.

According to Dindadhika (2018) "Poor sitting position and discomfort when sitting results in a change in sitting position during lectures and the learning process. So that it will cause musculoskeletal disorders in certain body parts and cause problems for students in the future, namely difficulty concentrating while studying. This can hurt student performance. Thus, it is necessary to improve the learning process, facilities, especially in the form of innovative chairs to accommodate student needs. The Kansei Engineering (KE) method is used to determine design engineering specifications with a mapping process of student feelings with 100 respondents, from these respondents obtained 8 Kansei words, namely comfortable, innovative design, durable, manageable, affordable, attractive colors, safe and easy to move. Anthropometric data is also used to support the design. Statistical analysis was performed to test the hypothesis. The results of this study indicate that the new innovative and 


\section{TiBuana}

ergonomic chair design is proven valid to meet user needs at $5 \%$ of the significance level.

According to Roestendi et al (2018), one of the factors that can improve the quality of student learning is the use of lecture chairs and desks during lectures. Therefore, it requires ergonomic, safe, and comfortable lecture chairs and desks when used in the lecture process. The purpose of this study is to find out what users need for ergonomic lecture chair products with an anthropometric approach, design a lecture chair design using AutoCAD in $3 \mathrm{D}$, material selection, product manufacturing, and questionnaires as product evaluation. Determining the level of the priority order of student needs for the attributes of lecture chairs is done using QFD (quality function deployment). Then it is necessary to calculate the cost of designing a product chair for students to find out the nominal value of the items sold, as well as control of production costs, including Cost of Production (HPP), Break-Even Point (BEP), Business Efficiency (R / c ratio), Net Present Value. (NPV), Internal Rate of Return (IRR), and Payback Period (PP). The identification of the QFD (quality function deployment) method shows that from the questionnaire distributed to respondents, it prioritizes chair design and the level of comfort when used in the lecture process, and from anthropometric, calculations the size results for college chairs with chair height $43 \mathrm{~cm}$, seat cover $52 \mathrm{~cm}$, area whiteboard $39 \mathrm{~cm}$, blackboard height 21 $\mathrm{cm}$, back height $49 \mathrm{~cm}$, backrest $52 \mathrm{~cm}$ width and the cost of production (HPP) is Rp. 322,213 per unit and a selling price of Rp. 418,877 per unit.

Darnianti. et al (2018) said that the purpose of designing a lecture chair with additional functions is to provide comfort to students when using a lecture chair for a long time, the ease of meeting the needs of students. Lecture chairs are designed according to the needs of students, including a comfortable seat, writing board equipment, a bag holder, and there is also a drinking area on the left. and so that students do not bother holding their bags while writing and listening to lecturers teach. The technique used in developing alternatives is through brainstorming. The use of this technique is by collecting some input obtained from students of one of the tertiary institutions. From the input obtained through brainstorming, a morphological map is made which is useful for selecting the best alternative in designing multipurpose lecture chair products.

According to Sanny et al. (2017) Campus is a learning process place for students where to support the comfort of students and teachers in the learning process, adequate facilities are needed inside the classroom and outside the classroom. Facilities that are not comfortable for their users will cause muscle injury disorders. Muscle injuries are caused due to the continuous accumulation of work equipment that is used causing discomfort and pain in certain parts of the body. The purpose of this study is to design chair and desk facilities for students on campus with the research limitation that this design is only intended for students who are on the Kadiri University campus, East Java. This design is expected to minimize the occurrence of muscle injury for students who use it. The results of the research resulted in the design of tables and chairs that are expected to meet the needs of users, especially students of Kadiri University, Kediri with profile iron sizes measuring 1.2 meters and 1.4 meters with manual sliding and nuts and bolts as the lock

\section{METHODOLOGY}

The method used in the manufacturing process of flexible chair is, determination of product components, making Bill of Materials, selection of production equipment and machines, determining the timing of the productionprocess, determination of required operators. 


\section{TiBuana}

Journal of applied Industrial Engineering-University of PGRI AdiBuana

DOI : https://doi.org/10.36456/tibuana.4.01.3172.16-22

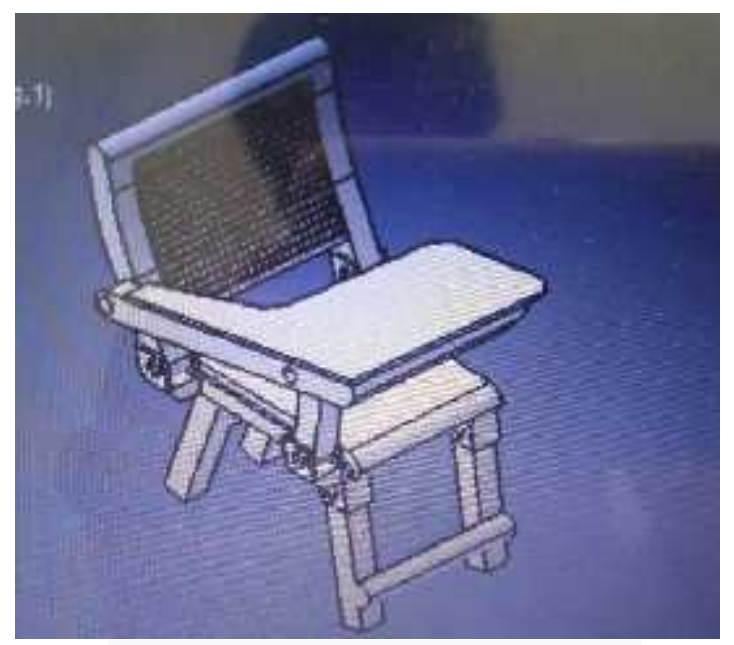

Figure 1 the proposed lecture chair

\section{RESULT AND DISCUSSION}

\section{Table 1 Determination of Product Components}

\begin{tabular}{|c|c|c|c|c|c|c|}
\hline Types & $\begin{array}{l}\text { Total } \\
\text { (Unit) }\end{array}$ & $\begin{array}{c}\text { Dimension } \\
\mathbf{s}\end{array}$ & Ingredient & Information & $\begin{array}{l}\text { Reason for } \\
\text { Purchase }\end{array}$ & Figure \\
\hline \multicolumn{7}{|c|}{ Main Framework } \\
\hline $\begin{array}{l}\text { Plate } \\
\text { Hollow Box } \\
\text { Iron }\end{array}$ & 5 & $100 \mathrm{~cm}$ & Iron & Beli & $\begin{array}{l}\text { The basic material } \\
\text { for making chairs } \\
\text { because it is } \\
\text { stronger }\end{array}$ & \\
\hline \multicolumn{7}{|l|}{ Headrests } \\
\hline $\begin{array}{l}\text { Galvalume } \\
\text { Oval }\end{array}$ & 3 & $50 \mathrm{~cm}$ & Iron & Beli & $\begin{array}{l}\text { The basic material } \\
\text { for making chairs } \\
\text { so that they are } \\
\text { stronger to } \\
\text { support the load }\end{array}$ & \\
\hline Grill Plate & 1 & $\begin{array}{l}54 \times 110 \\
\mathrm{~cm}\end{array}$ & Iron & Beli & $\begin{array}{l}\text { The basic material } \\
\text { for making chairs } \\
\text { to be stronger }\end{array}$ & \\
\hline $\begin{array}{l}\text { Electrode } \\
\text { welding }\end{array}$ & 1 Box & - & Electrode & Buy & $\begin{array}{l}\text { The basic material } \\
\text { of electric } \\
\text { welding } \\
\text { (electrodes) }\end{array}$ & vere: \\
\hline \multicolumn{7}{|l|}{ Foot rests } \\
\hline Hollow Iron & 1 & $100 \mathrm{~cm}$ & Iron & Buy & $\begin{array}{l}\text { As a footrest to be } \\
\text { strong }\end{array}$ & 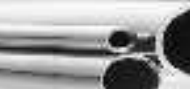 \\
\hline
\end{tabular}




\section{TiBuana}

Journal of applied Industrial Engineering-University of PGRI AdiBuana

DOI : https://doi.org/10.36456/tibuana.4.01.3172.16-22

$$
1 \quad 100 \mathrm{~cm} \quad \text { Iron Buy }
$$

\begin{tabular}{|c|c|c|c|c|c|c|}
\hline \multicolumn{7}{|l|}{ Back Frame } \\
\hline $\begin{array}{l}\text { Hollow Oval } \\
\text { Iron }\end{array}$ & 1 & $\begin{array}{l}\text { P: } 200 \mathrm{~cm} \\
\text { dan L: } \\
50 \mathrm{~cm}\end{array}$ & iron & Buy & As a seat support & \\
\hline Plate & 1 & $\begin{array}{l}\text { P: } 200 \mathrm{~cm} \\
\text { dan L: } \\
\quad 50 \mathrm{~cm}\end{array}$ & Besi & Buy & $\begin{array}{l}\text { As a seat to make } \\
\text { it more } \\
\text { comfortable }\end{array}$ & \\
\hline Spons & 1 & $\begin{array}{l}\text { P: } 200 \mathrm{~cm} \\
\text { dan L: } \\
50 \mathrm{~cm}\end{array}$ & Static Foam & Buy & $\begin{array}{l}\text { As a seat to make } \\
\text { it more } \\
\text { comfortable and } \\
\text { soft }\end{array}$ & \\
\hline wood & 1 Lonjor & $P: 100 \mathrm{~cm}$ & $\begin{array}{l}\text { Karbon } \\
\text { Wood }\end{array}$ & Buy & Foam seat mat & \\
\hline $\begin{array}{l}\text { Karbon } \\
\text { Wood }\end{array}$ & 1 Lonjor & $\begin{array}{l}\text { P: } 100 \mathrm{~cm} \\
\text { dan } \quad \mathrm{L}: \\
50 \mathrm{~cm}\end{array}$ & $\begin{array}{l}\text { Karbon } \\
\text { Wood }\end{array}$ & Buy & Place to study & \\
\hline \multicolumn{7}{|l|}{ Adjuvant } \\
\hline Fox Glue & 1 & $45 \mathrm{~g}$ & Glue & Buy & $\begin{array}{l}\text { For gluing } \\
\text { sponges and seat } \\
\text { supports }\end{array}$ & \\
\hline Nut and Bolt & 1 & nut 12 & Iron & Buy & Plate lock & 6 \\
\hline Hinge & 1 & $100 \mathrm{~mm}$ & Iron & Buy & $\begin{array}{l}\text { To lock the } \\
\text { hollow pipe base }\end{array}$ & $x^{2}=$ \\
\hline Lock & 1 & $10 \mathrm{~mm}$ & Iron & Buy & $\begin{array}{l}\text { As locking leg } \\
\text { supports }\end{array}$ & \\
\hline Firing Nails & 1 box & $10 \mathrm{~mm}$ & Iron & Buy & $\begin{array}{l}\text { Fix the carpet } \\
\text { with a base } \\
\text { sponge }\end{array}$ & \\
\hline
\end{tabular}




\section{TiBuana}

Journal of applied Industrial Engineering-University of PGRI AdiBuana

DOI : https://doi.org/10.36456/tibuana.4.01.3172.16-22

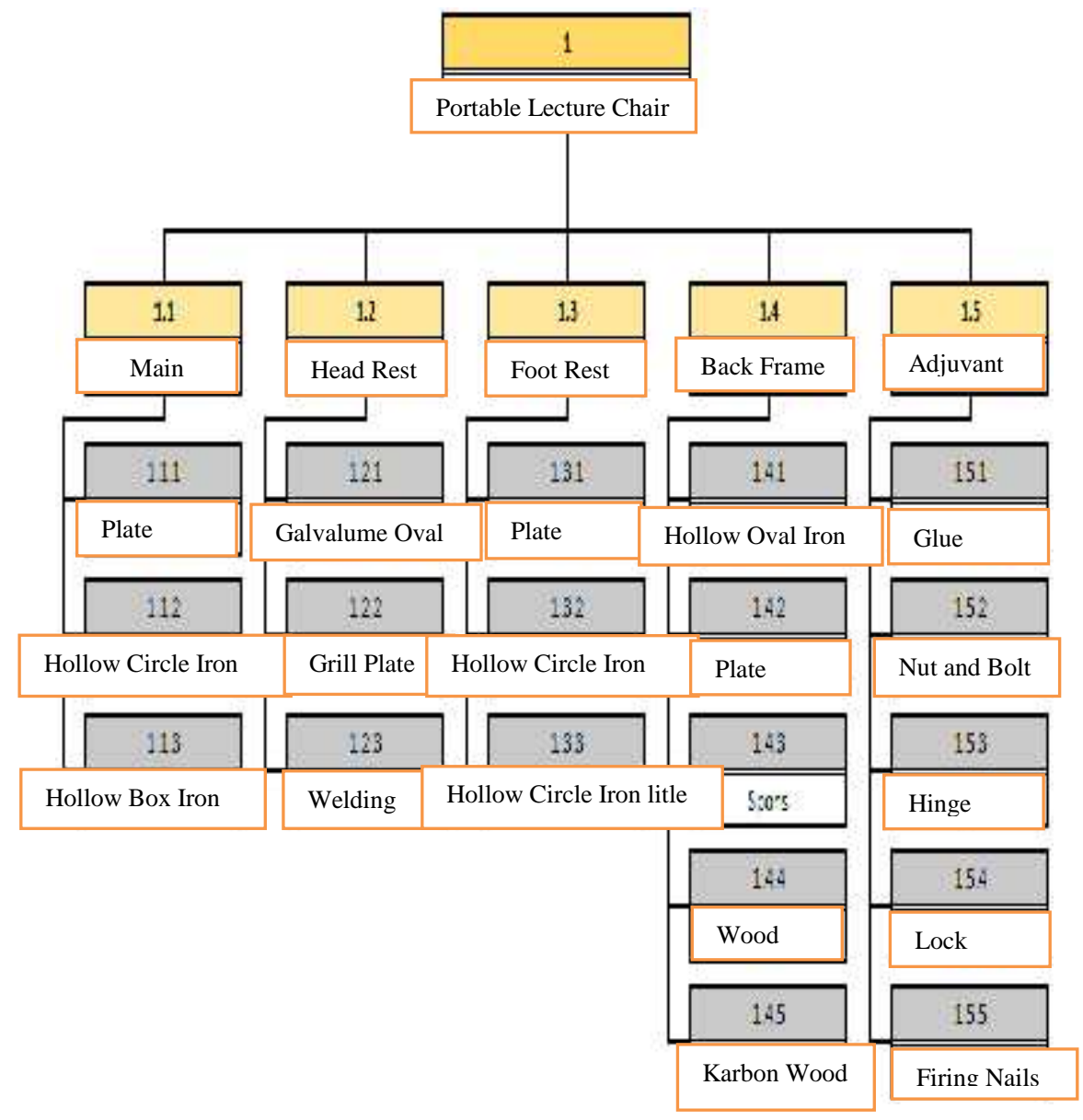

Figure 2 Bill of Materials

\section{Selection Of Production Equipment And Machines}

CO2 welding

Wrench (Adjustable Spanner)

Screwdriver $+/-$

"L" key

Wrench 8,10,12,14,16,18

Hammer

Tang

Grinders

Shirkel

Drill
Meter

Sketch

Pinch Pliers

Vise

Chainsaw

Plate Scissors

Outlet

Cable stretching

Staples

Air compressor + Paint 


\section{TiBuana}

Journal of applied Industrial Engineering-University of PGRI AdiBuana

DOI : https://doi.org/10.36456/tibuana.4.01.3172.16-22

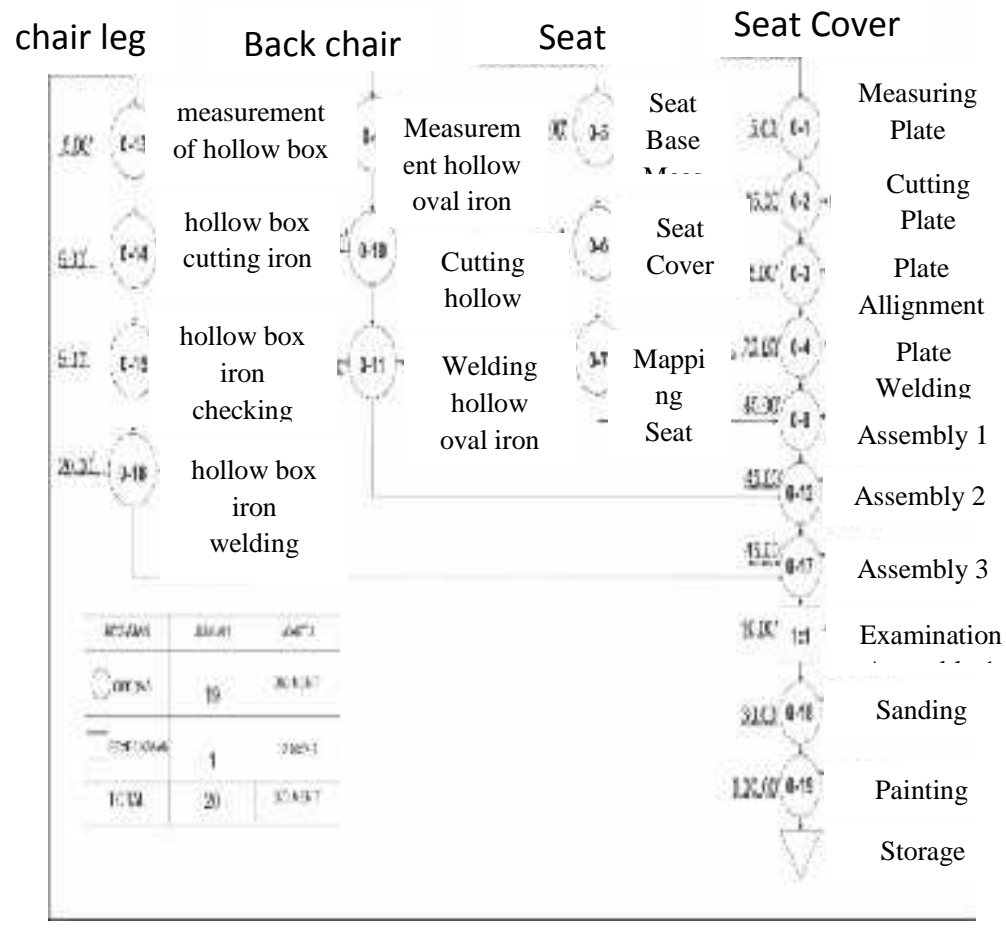

Figure 3 determining the timing of the production process

\begin{tabular}{|c|}
\hline Gist Erabie oflos \\
\hline Isisfritare \\
\hline
\end{tabular}
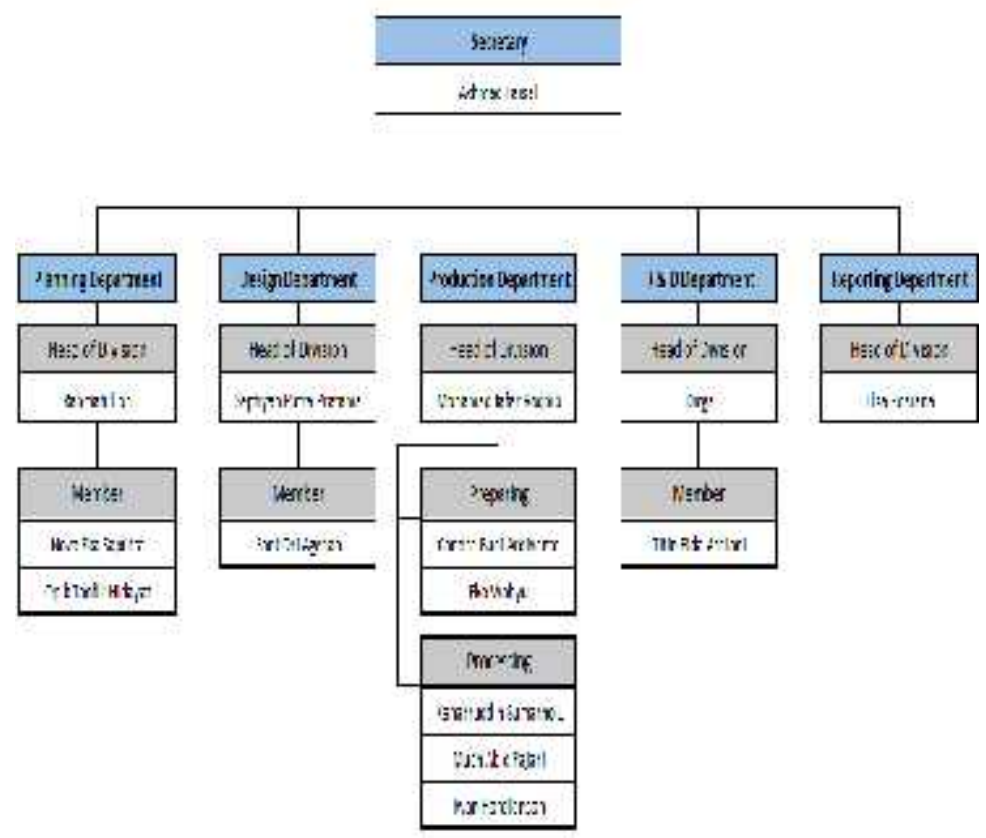

Figure 4 determination of required operators 
TiBuana

Journal of applied Industrial Engineering-University of PGRI AdiBuana

DOI : https://doi.org/10.36456/tibuana.4.01.3172.16-22

\section{CONCLUSION}

The manufacturing process that we carried out for the manufacture of our redesigned lecture chairs (flexible chair) has been produced with a total time of 370 minutes with parts, namely, the mainframe, headrests, leg rests, frame back, and supporting materials with a total of 5 operators. We hope that this article can help other fellow students to produce an item and make an analysis of the production process.

\section{REFERENCES}

1. Alfatiyah, Rini\&Mathin, William (2017). Redesign Kursi dan MejaPerkuliahandenganMetodeQuality Function Deployment (Qfd) SecaraErgonomis di Program Studi Teknik Industri Universitas Pamulang. Prosiding Seminar IlmiahNasional :"MembangunParadigmaKehidupan MelaluiMultidisiplinIlmu”.

2. Dindandhika, Ken Arum (2018). Desain UlangKursiKuliah yang Inovatif dan Ergonomis. Tugas Akhir Mahasiswa Universitas Islam Indonesia.
3. ResheniyaIzobretatelskikhZadatch (Triz) (StudiKasus : Perusahaan KueKembangWaru, Candirejo, Klaten). Institutional Repository :Skripsi Thesis UIN SunanKalijaga.

4. Roestendi, Rizal. dkk (2018). Analisa KelayakanRancangBangunUlangKurs iPerkuliahan yang Ergonomis. Jurnal Online Teknik Industri Universitas TujuhBelasAgustus 1945 Surabaya :http://industri.untagsby.ac.id/backend/uploads/pdf/ANAL ISA_KELAYAKAN_RANCANG_B ANGUN_ULANG_KURSI_PERKUL IAHAN_YANG_ERGONOMIS.pdf.

5. Darnianti\&Sinambela, Yusnia (2018). Desain KursiKuliahDenganMetode Brainstorming Di Fakultas Teknik Universitas Quality Medan. Juitech / Vol.02 / No. 02 / Oktober 2018 / pISSN : 2580-4057 / e-ISSN : 25977261.

6. Andjar Sari, Sanny\&Rahayuningsih, Sri (2017).PerancanganMeja dan Kursi Taman UntukMahasiswa (StudiKasus :Mahasiswa Universitas Kadiri).Seminar Nasional Teknologi dan Rekayasa (SENTRA) 2017 ISSN (Cetak) 2527-6042 eISSN (Online) 2527-6050 